\title{
Structure Determination of Macrolactin Compounds with Antibacterial Activities Isolated from Bacillus polyfermenticus KJS-2
}

\author{
Dong-Hee Kim', Kyung-Ran Kang1, Hyun-Woo Kim², Si-Yeol Yoon³, Chun-Gyu Kim³, \\ Tokutaro Yamaguchi', Jae Kyung Sohng ${ }^{4}$ and Jae Seon Kang ${ }^{5}$ \\ ${ }^{1}$ Research and Development Center, Daewoo Pharmaceutical Co, Ltd, Busan 603-838, Korea \\ ${ }^{2}$ Technical Research Institute, Daesun Distilling Co, Ltd Busan 619-934, Korea \\ ${ }^{3}$ Department of Pharmaceutical Engineering Inje University, Gimhae city, Gyeongnam 621-749, Korea \\ ${ }^{4}$ Department of Pharmaceutical Engineering Sun Moon University, Asan city, Chungnam 336-708, Korea \\ ${ }^{5}$ Department of Pharmacy, Kyungsung University, Busan 608-736, Korea
}

Received November 5, 2010 /Accepted December 16, 2010

\begin{abstract}
In this study, we isolated five macrolactin compounds from a fermentation broth of Bacillus polyfermenticus KJS-2. The macrolactin compounds were structurally identified as macrolactin A (MA), 7-O-malonyl macrolactin A (MMA), 7-O-succinyl macrolactin A (SMA), macrolactin E (ME) and macrolactin F (MF) via a variety of NMR techniques, COZY, DEPT, HMQC and HMBC, and mass and specific rotation assays. The three macrolactin compounds, MA, MMA and SMA, profoundly inhibited the growth of both vancomycin-resistant Enterococci (VREs) and methicillin-resistant Staphylococcus aureus (MRSA), the inhibition of which were estimated via a disc agar diffusion bioassay. MA, MMA, and SMA exhibited antibacterial activities superior to those of vancomycin and teicoplanin.
\end{abstract}

Key words : Bacillus polyfermenticus KJS-2, macrolactin, antibacterial activity, vancomycin-resistant Enterococcus, methicillin-resistant Staphylococcus aureus

\section{Introduction}

The macrolactin compounds are a class of macrolide antibiotics, all of which contain a 24-membered lactone ring [8]. They were isolated from several natural sources, an unclassifiable marine bacterium, Streptomyces, Actinomadura, and Bacillus species $[4,8,11,16]$. Thus far, 26 macrolactin compounds have been structurally elucidated [8,16,21,22,26-28].

Macrolactins evidence a variety of structures, as well as broad pharmacological activities. MA inhibits not only proliferation of murine melanoma cancer cell and Herpes simplex virus [8], but also the synthesis of the enzyme squalene synthase [4]. Additionally, MA appears to be capable of protecting neuronal cells against glutamate toxicity [11] and also protects $\mathrm{T}$ lymphoblast cells against injury by the human immunodeficiency virus (HIV) [8]. The macrolactin compounds exhibit a marked antimicrobial activity [8-10,14,16, 22,26]. MMA and SMA also inhibit the growth of the dangerous Gram-positive bacteria, MRSAs and VREs [21].

We have been primarily interested in macrolactin compounds and their numerous pharmacological activities, most

*Corresponding author

Tel : +82-51-663-4802, Fax : +82-51-663-4809

E-mail : jskang8551002@ks.ac.kr specifically the antibacterial activities evidenced by some macrolactin compounds against multidrug-resistant bacteria.

Increased resistance to antimicrobial agents and the emergence of multidrug-resistant gram-positive bacterial pathogens, including MRSA and VRE, have become pressing issues in the medical community[17,18,20]. These organisms induce nosocomial infections and are associated with increased rates of morbidity and mortality $[5,7,25]$. The glycopeptide antibiotics vancomycin and teicoplanin are commonly employed to treat infections caused by MRSA and VRE [19,24]. However, recent emergences of infections evidencing high-level resistance to these glycopeptide antibiotics have resulted in restrictions being placed on their use for the treatment of nosocomial infections [1,3]. Linezolid, a novel synthetic oxazolidinone compound, has been identified as a potential alternative against MRSA and VRE $[6,15,29]$. However, linezolid-resistant Enterococci have already been reported $[2,23]$. Thus, the development of new antibiotics is clearly necessary in order to overcome these bacterial infections.

Bispan strains are recognized in the Japanese pharmacopoeia as amylolytic bacilli and commercial probiotic bacteria mixed with at least four strains of Bacillus polyfermenticus [13]. In a previous study, we newly isolated B. poly- 
fermenticus KJS-2 from these Bispan strains [12].

In the process of surveying the antibacterial activity of secondary metabolites generated by B. polyfermenticus KJS-2 against VREs and MRSAs, we identified the five macrolactin compounds as major components evidencing antibacterial activities.

In this paper, we report the isolation, purification, structural elucidation, and antibacterial activities of macrolactin compounds generated by B. polyfermenticus KJS-2.

\section{Materials and Methods}

\section{Strains and media}

The following standard strains were employed in this study: Enterococcus faecalis ATCC29212 and Staphylococcus aureus subsp. aureus ATCC25923. Clinical isolates of vancomycin-resistant Enterococcus faecium (VanA type, VRE-1, VRE-2) and methicillin-resistant Staphylococci (MRSA-4, MRSA-9) were obtained from the Dong-A University Medical Center and Kyungsung University, respectively, both of which are located in Busan, Korea. All bacteria were cultivated at $35^{\circ} \mathrm{C}$ and $200 \mathrm{rpm}$ for $24 \mathrm{hr}$ in tryptic soy broth (TSB, Difco). All organisms were maintained in $25 \%$ glycerol solution at $-72^{\circ} \mathrm{C}$ for short-term storage and freeze-dried with $10 \%$ skim milk for long-term storage.

\section{Chemicals}

Vancomycin, methicillin, and ampicillin were purchased from Sigma. Teicoplanin was obtained from IL-DONG Pharmaceutical Co., LTD. Antibiotic stock solutions were freshly prepared in sterile distilled water. Stock solutions of MA, MMA, SMA, ME and MF were freshly prepared in methanol.

\section{Culture and extraction}

B. polyfermenticus KJS-2 was used to produce macrolactins. The strain was grown in TSB medium, which functioned as the seeding medium. The seeding medium $(280 \mathrm{ml})$ was cultured at $37^{\circ} \mathrm{C}$ on a rotary shaker at $200 \mathrm{rpm}$ until the culture reached an $\mathrm{OD}_{600}$ of 0.7 , and then inoculated into a fermentor (10 1, Biotron, Korea) containing 71 of fermentation medium. The fermentation medium consisted of $16 \mathrm{~g}$ of nutrient broth (Difco), $2.5 \mu \mathrm{M} \mathrm{FeSO}_{4}, 500 \mu \mathrm{M} \mathrm{CaCl}_{2}, 10 \mu \mathrm{M} \mathrm{MnCl}_{2}, 1 \mathrm{mM}$ $\mathrm{MgSO}_{4}, 13 \mathrm{mM} \mathrm{KCl}$, and $10 \mathrm{~g}$ of skim milk in a total volume of $1 \mathrm{~L}$.

To produce MA, MMA, ME and MF, fermentation was conducted at $30^{\circ} \mathrm{C}$ with an agitation rate of $200 \mathrm{rpm}$ and an aeration rate of $1.0 \mathrm{l} / \mathrm{min}$. The $\mathrm{pH}$ was maintained at 6.8 via the addition of $2 \mathrm{~N} \mathrm{H}_{2} \mathrm{SO}_{4}$ and $3 \mathrm{~N} \mathrm{NaOH}$.

The fermentation broth was extracted three times with an equal volume of ethyl acetate. The ethyl acetate layer was evaporated under vacuum. The residue was dissolved in methanol.

To generate SMA, the seeding culture $(40 \mathrm{ml})$ was inoculated into 11 of TSB medium supplemented with $50 \mathrm{ml}$ of HP-20 resin. Following 2.5 days of incubation at $30^{\circ} \mathrm{C}$ and $200 \mathrm{rpm}$, the culture broth was filtered to collect HP-20 resins. The collected resins were then washed for $1 \mathrm{hr}$ with $250 \mathrm{ml}$ of ethyl acetate, and this procedure was repeated three times. The eluted solvent was evaporated under vacuum, and the final residue was dissolved in methanol.

\section{Medium pressure liquid chromatography (MPLC) separation}

For the partial purification of a macrolactin compound, the extract was fractionated with a Buchi MPLC system (Buchi pump C-605, column $1.5 \times 23 \mathrm{~cm}$, fraction collector Buchi C-660) using LiChroprep C-18 (40 63 $\mu \mathrm{m}$, Merck) as an adsorbent. The MPLC conditions were as follows: $40 \%$ acetonitrile or $40 \%$ acetonitrile containing $20 \mathrm{mM}$ ammonium acetate was maintained at a flow rate of $15 \mathrm{ml} / \mathrm{min}$ for the first $800 \mathrm{sec}$, after which $100 \%$ methanol was maintained with a flow rate of $20 \mathrm{ml} / \mathrm{min}$ from 800 to $1200 \mathrm{sec}$ on an MPLC chromatograph. Elution was monitored at 262 nm.

Each of the fractions was evaporated in vacuo and extracted with ethyl acetate and water. The ethyl acetate layer was evaporated under reduced pressure, after which the residue was dissolved in methanol.

\section{Semi-preparative HPLC separation}

To achieve higher purity, each of the MPLC fractions was injected into a semi-preparative liquid chromatography apparatus (Young-Lin Co. Ltd., Korea) equipped with a Gemini C18 column (250 by $10 \mathrm{~mm}$, Phenomenex Co., Ltd.). 40\% acetonitrile solution was maintained at a flow rate of $5 \mathrm{ml} / \mathrm{min}$. The pooled fractions were evaporated under vacuum and extracted with ethyl acetate and water. The ethyl acetate layer was evaporated under reduced pressure, and a pale yellow or off-white powder was subsequently generated. Each of the powders was stored at $-20^{\circ} \mathrm{C}$. 


\section{Conditions for HPLC and LC/Mass analysis}

HPLC and LC/Mass analysis were conducted using a Shimadzu class vp and Agilent 1100 seriesapparatus, respectively. The Agilent 1100 series contains a high pressure liquid chromatograph connected to an online diode array detector (DAD) and a mass selective detector (MSD) equipped with an electrospray ionization chamber. A Zorbax SB C18 column (dimensions, 250 by $4.6 \mathrm{~mm}$ ) was used for HPLC and LC/Mass analysis. The mobile phase consisted of acetonitrile and water including $0.1 \%$ formic acid. The acetonitrile concentration increased in a linear fashion from 0 to $100 \%$ for $20 \mathrm{~min}$. The UV wavelength was set at 262 $\mathrm{nm}$. The flow rates of the mobile phase in HPLC and LC/Mass were 1.5 and $1 \mathrm{ml} / \mathrm{min}$, respectively. For LC/Mass analysis, the flow was directly introduced into the ESI interface. The capillary voltage was set to $4 \mathrm{kV}$, the drying gas temperature was $300^{\circ} \mathrm{C}$, the dry gas flow was $12 \mathrm{l} / \mathrm{min}$, and the nebulizer pressure was set to 50 psi.

\section{Structure determination}

For nuclear magnetic resonance (NMR) spectroscopy, 30 $\mathrm{mg}$ of the purified compound was dissolved in DMSO- $d_{6}$. ${ }^{1} \mathrm{H}-\mathrm{NMR}$, selective homonuclear-decoupled, ${ }^{13} \mathrm{C}-\mathrm{NMR}$, DEPT-45, DEPT-90, DEPT-135, ${ }^{1} \mathrm{H}^{-1} \mathrm{H}$ COZY, HMQC and HMBC spectra were recorded using a Brucker Advance DRX 500 spectrometer operating at $500 \mathrm{MHz}$. For specific rotation measurements, $40 \mathrm{mg}$ of the compound was dissolved in $1 \mathrm{ml}$ of $\mathrm{MeOH}$. The solution was transferred into the tube (length=100 mm, volume=1 ml), after which the specific rotation was measured using a POLAX-D polarimeter (Atago, Germany).

\section{Antibacterial activities by agar diffusion bioassay}

A cell suspension was overlaid on a cation-adjusted
Mueller-Hinton agar plate $\left(5 \times 10^{5} \mathrm{cfu} /\right.$ plate $)$. Sterile discs $(6$ mm AA discs, Whatman) impregnated with $10 \mu$ of the antibiotic stock solution or the sample stock solutions (the final compound concentration on the disc, $50 \mu \mathrm{g}$ ) were placed on the agar plates. $10 \mu \mathrm{l}$ of $\mathrm{MeOH}$ was employed as a control. All bacteria were incubated for $18 \mathrm{hr}$ at $35^{\circ} \mathrm{C}$. After incubation, the diameters $(\mathrm{mm})$ of the inhibition zones were measured with a ruler.

\section{Results}

\section{MPLC fractionation and antibacterial activities}

The fermentation broth was extracted with ethyl acetate, and subsequently equally divided into three fractions by MPLC. Each of the MPLC fractions was then analyzed via LC/Mass, and their anti-VRE and anti-MRSA activities were assessed via a paper disc-agar diffusion bioassay. The large inhibition zones of bacterial growth were observed around the discs. Interestingly, both of the second and third MPLC fractions strongly inhibited the growth of VREs and MRSAs. Table 1 provides their anti-VRE and anti-MRSA activities. The UV spectra and mass data resulting from the LC/Mass analysis of two MPLC fractions suggested that their major components might be macrolactin compounds. Fig. 2 shows LC chromatograms of the crude extract and the three fractions divided by MPLC.

\section{Production, isolation, and structure determination of five macrolactin compounds}

Five major compounds were purified from a fermentation broth of Bp2. The production yield of compound I was estimated as $58 \mathrm{mg} / \mathrm{l}$. The purity was $98.3 \%$ on the HPLC chromatogram observed at a UV wavelength of $262 \mathrm{~nm}$. Compound I evidenced a $425.4[\mathrm{M}+\mathrm{Na}]^{+}$and $441.4[\mathrm{M}+\mathrm{K}]^{+}$

Table 1. Antibacterial activities of the crude extract and three fractions divided by MPLC

\begin{tabular}{|c|c|c|c|c|c|}
\hline \multirow{3}{*}{ Strain } & \multirow{3}{*}{ Class of bacteria } & \multicolumn{4}{|c|}{ Inhibition diameter (mm) } \\
\hline & & \multirow{2}{*}{$\begin{array}{l}\text { Crude } \\
\text { extract }\end{array}$} & \multicolumn{3}{|c|}{ MPLC fractions } \\
\hline & & & 1 st & 2nd & $3 r d$ \\
\hline E. faecalis ATCC29212 & Gram positive & 12 & - & 12 & 8 \\
\hline VRE-1 & Gram positive & 15 & - & 14 & 13 \\
\hline VRE-2 & Gram positive & 17 & - & 17 & 14 \\
\hline S. aureus ATCC25923 & Gram positive & 25 & 13 & 25 & 23 \\
\hline MRSA- 4 & Gram positive & 30 & 16 & 30 & 30 \\
\hline MRSA-9 & Gram positive & 33 & 23 & 33 & 32 \\
\hline
\end{tabular}

E. faecalis ATCC29212, Enterococcus faecalis ATCC29212; VRE, vancomycin-resistant Enterococcus faecium S. aureus ATCC25923, Staphylococcus aureus ATCC25923; MRSA, methicillin-resistant Staphylococcus aureus See materials and methods for experiment procedures. 

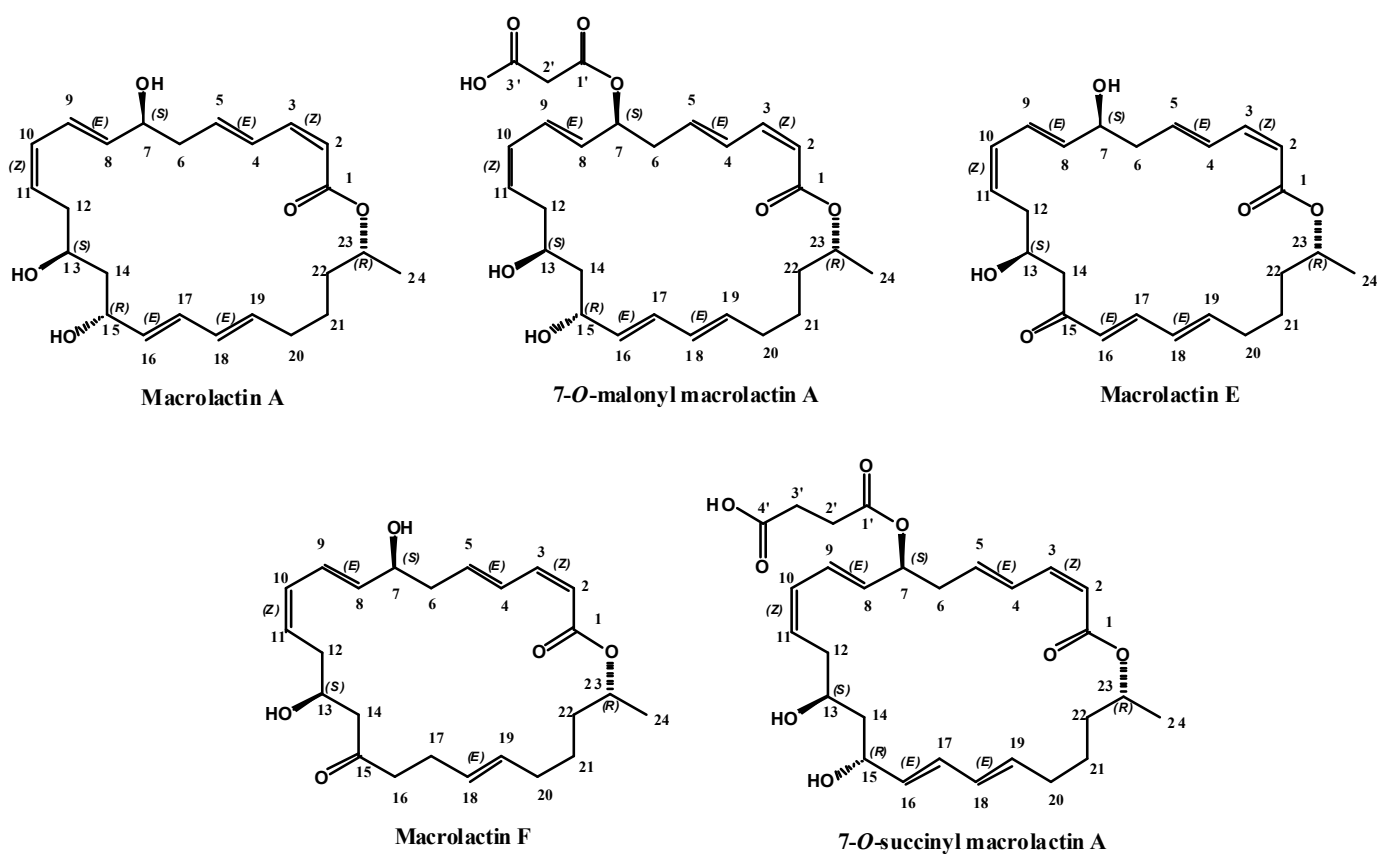

Fig. 1. Chemical structures of five macrolactin compounds produced from B. polyfermenticus KJS-2.

a)

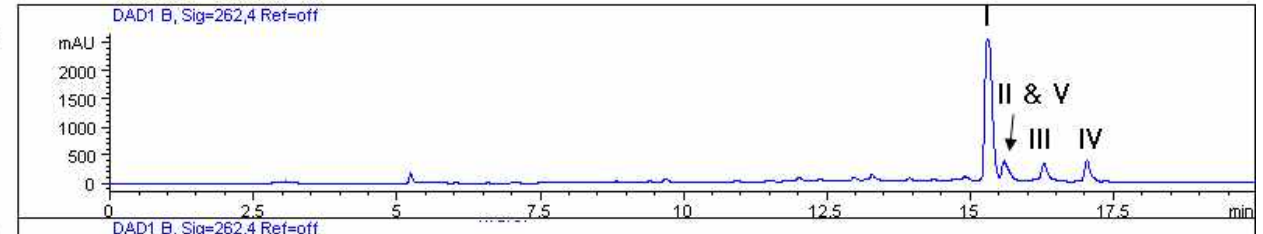

b)

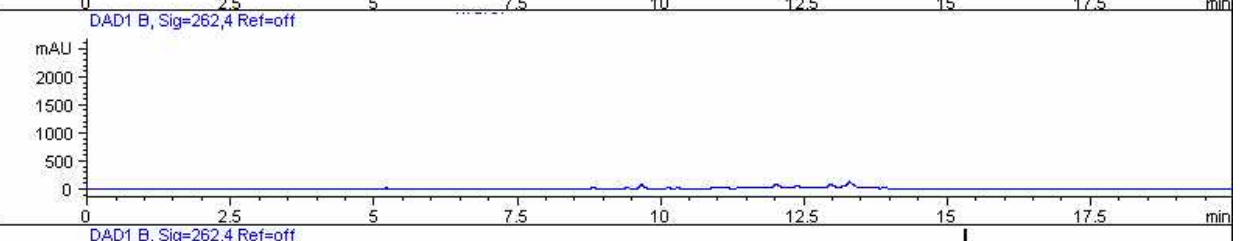

c)

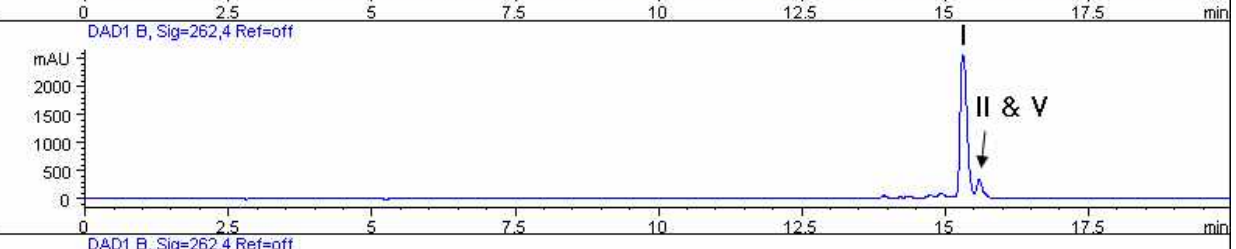

d)

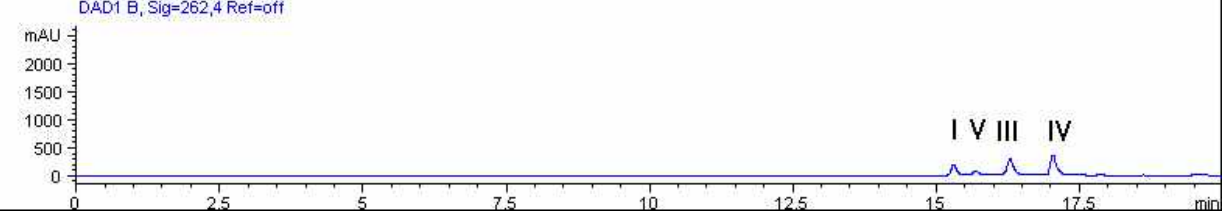

Fig. 2. LC chromatograms of the crude extract and three fractions divided by MPLC. a), LC chromatogramsof the crude extract, b), c) and d) 1st, 2nd and 3rd fraction, respectively. Roman numerals indicate the peaks which were identified as macrolactins. LC chromatogram was generated at $262 \mathrm{~nm}$ of UV wavelength.

mass-to-charge ratio in the $(+)$ ESI-mass spectrum. The maximal absorptions observed were at 230 and $262 \mathrm{~nm}$ in the UV spectrum. Compound I was identified as a monocyclic compound composed of $\mathrm{C}_{24} \mathrm{H}_{34} \mathrm{O}_{5}$, via analysis of the ${ }^{1} \mathrm{H}-{ }^{1} \mathrm{H}$
COZY, HMQC, and HMBC NMR spectra (Table 2). However, these data were not sufficient to elucidate the structure because the ${ }^{1} \mathrm{H}$ NMR spectrum included complex peaks. For this reason, a selective homonuclear decoupling 
Table 2. ${ }^{1} \mathrm{H}$ NMR data (500 MHz) of compounds $1-5$ in DMSO- $d b^{a}$

\begin{tabular}{|c|c|c|c|c|c|}
\hline $\begin{array}{c}\text { Carbon } \\
\text { No }\end{array}$ & 1 & 2 & 3 & 4 & 5 \\
\hline 2 & $5.55(1 \mathrm{H}, \mathrm{d}, 11.68)$ & $5.58(1 \mathrm{H}, \mathrm{d}, 11.38)$ & $5.55(1 \mathrm{H}, \mathrm{d}, 11.50)$ & $5.54(1 \mathrm{H}, \mathrm{d}, 11.53)$ & $5.56(1 \mathrm{H}, \mathrm{d}, 11.47)$ \\
\hline 3 & $6.65(1 \mathrm{H}, \mathrm{dd}, 11.54,11.51)$ & $6.62(1 \mathrm{H}, \mathrm{dd}, 11.34,11.92)$ & $6.66(1 \mathrm{H}, \mathrm{dd}, 11.50,11.51)$ & $6.65(1 \mathrm{H}, \mathrm{dd}, 11.51,11.55)$ & $6.63(1 \mathrm{H}, \mathrm{dd}, 11.48,11.51)$ \\
\hline 4 & $7.06(1 \mathrm{H}, \mathrm{dd}, 11.56,15.13)$ & $7.1(1 \mathrm{H}, \mathrm{dd}, 11.74,15.65)$ & $7.07(1 \mathrm{H}, \mathrm{dd}, 11.49,15.12)$ & $7.11(1 \mathrm{H}, \mathrm{dd}, 11.36,15.26)$ & $7.09(1 \mathrm{H}, \mathrm{dd}, 11.63,15.1)$ \\
\hline 5 & $6.19(1 \mathrm{H}, \mathrm{dt}, 15.17,14.68)$ & $6.1(1 \mathrm{H}, \mathrm{dt}, 15.23,14.62)$ & $6.21(1 \mathrm{H}, \mathrm{m})$ & $6.2(1 \mathrm{H}, \mathrm{dt}, 15.35,14.93)$ & $6.08(1 \mathrm{H}, \mathrm{dt}, 15.15,14.71)$ \\
\hline 6 & $2.32(2 \mathrm{H}, \mathrm{m})$ & $2.54(2 \mathrm{H}, \mathrm{m})$ & $\begin{array}{l}2.32(1 \mathrm{H}, \mathrm{m}) \\
2.25(1 \mathrm{H}, \mathrm{m})\end{array}$ & $2.33(2 \mathrm{H}, \mathrm{m})$ & $2.56(2 \mathrm{H}, \mathrm{m})$ \\
\hline 7 & $4.16(1 \mathrm{H}, \mathrm{m})$ & $5.39(1 \mathrm{H}, \mathrm{m})$ & $4.08(1 \mathrm{H}, \mathrm{m})$ & $4.12(1 \mathrm{H}, \mathrm{m})$ & $5.38(1 \mathrm{H}, \mathrm{m})$ \\
\hline 8 & $5.71(1 \mathrm{H}, \mathrm{dd}, 5.23,15.16)$ & $5.72(1 \mathrm{H}, \mathrm{dd}, 5.68,15.41)$ & $5.71(1 \mathrm{H}, \mathrm{dd}, 6.07,15.18)$ & $5.71(1 \mathrm{H}, \mathrm{dd}, 6.12,15.26)$ & $5.71(1 \mathrm{H}, \mathrm{dd}, 5.48,15.24)$ \\
\hline 9 & $6.48(1 \mathrm{H}, \mathrm{dd}, 15.06,11.21)$ & $6.53(1 \mathrm{H}, \mathrm{dd}, 15.26,11.08)$ & $6.34(1 \mathrm{H}, \mathrm{dd}, 15.12,11.2)$ & $6.34(1 \mathrm{H}, \mathrm{dd}, 15.24,11.1)$ & $6.47(1 \mathrm{H}, \mathrm{dd}, 15.15,11.17)$ \\
\hline 10 & $6.02(1 \mathrm{H}, \mathrm{dd}, 10.90,10.85)$ & $6.04(1 \mathrm{H}, \mathrm{dd}, 11.33,10.63)$ & $6.06(1 \mathrm{H}, \mathrm{dd}, 11.2,10.96)$ & $6.04(1 \mathrm{H}, \mathrm{dd}, 11.05,11.05)$ & $6.05(1 \mathrm{H}, \mathrm{dd}, 11.08,10.5)$ \\
\hline 11 & $5.49(1 \mathrm{H}, \mathrm{m})$ & $5.59(1 \mathrm{H}, \mathrm{m})$ & $5.47(1 \mathrm{H}, \mathrm{m})$ & $5.45(1 \mathrm{H}, \mathrm{m})$ & $5.59(1 \mathrm{H}, \mathrm{m})$ \\
\hline 12 & $2.36(1 \mathrm{H}, \mathrm{m})$ & $2.4(1 \mathrm{H}, \mathrm{m})$ & $2.28(2 \mathrm{H}, \mathrm{m})$ & $2.26(2 \mathrm{H}, \mathrm{m})$ & $2.41(1 \mathrm{H}, \mathrm{m})$ \\
\hline & $2.14(1 \mathrm{H}, \mathrm{m})$ & $2.17(1 \mathrm{H}, \mathrm{m})$ & & & $2.17(1 \mathrm{H}, \mathrm{m})$ \\
\hline 13 & $3.64(1 \mathrm{H}, \mathrm{m})$ & $3.67(1 \mathrm{H}, \mathrm{m})$ & $4.02(1 \mathrm{H}, \mathrm{m})$ & $3.96(1 \mathrm{H}, \mathrm{m})$ & $3.64(1 \mathrm{H}, \mathrm{m})$ \\
\hline 14 & $1.42(2 \mathrm{H}, \mathrm{m})$ & $1.4(2 \mathrm{H}, \mathrm{m})$ & $\begin{array}{l}2.71(1 \mathrm{H}, \mathrm{dd}, 6.48,15.25) \\
2.53(1 \mathrm{H}, \mathrm{m})\end{array}$ & $2.44(2 \mathrm{H}, \mathrm{d}, 6.51)$ & $1.42(2 \mathrm{H}, \mathrm{m})$ \\
\hline 15 & $4.14(1 \mathrm{H}, \mathrm{m})$ & $4.16(1 \mathrm{H}, \mathrm{m})$ & & & $4.15(1 \mathrm{H}, \mathrm{m})$ \\
\hline 16 & $5.49(1 \mathrm{H}, \mathrm{dd}, 6.15,14.85)$ & $5.52(1 \mathrm{H}, \mathrm{dd}, 6.04,14.62)$ & $5.99(1 \mathrm{H}, \mathrm{d}, 15.56)$ & $2.38(2 \mathrm{H}, \mathrm{t}, 7.745)$ & $5.52(1 \mathrm{H}, \mathrm{dd}, 6.12,14.52)$ \\
\hline 17 & $6.04(1 \mathrm{H}, \mathrm{dd}, 14.84,10.35)$ & $6.03(1 \mathrm{H}, \mathrm{m})$ & $7.08(1 \mathrm{H}, \mathrm{m})$ & $2.1(2 \mathrm{H}, \mathrm{m})$ & $6.06(1 \mathrm{H}, \mathrm{dd}, 14.12,10.63)$ \\
\hline 18 & $5.96(1 \mathrm{H}, \mathrm{dd}, 10.50,14.62)$ & $6.0(1 \mathrm{H}, \mathrm{dd}, 10.58,14.52)$ & $6.24(1 \mathrm{H}, \mathrm{m})$ & $5.35(1 \mathrm{H}, \mathrm{m})$ & $6.0(1 \mathrm{H}, \mathrm{dd}, 10.53,14.99)$ \\
\hline 19 & $5.59(1 \mathrm{H}, \mathrm{dt}, 14.36,14.18)$ & $5.57(1 \mathrm{H}, \mathrm{m})$ & $6.23(1 \mathrm{H}, \mathrm{m})$ & $5.36(1 \mathrm{H}, \mathrm{m})$ & $5.59(1 \mathrm{H}, \mathrm{dt}, 14.52,13.85)$ \\
\hline 20 & $2.07(2 \mathrm{H}, \mathrm{m})$ & $2.07(2 \mathrm{H}, \mathrm{m})$ & $\begin{array}{l}2.26(1 \mathrm{H}, \mathrm{m}) \\
2.14(1 \mathrm{H}, \mathrm{m})\end{array}$ & $1.94(2 \mathrm{H}, \mathrm{m})$ & $2.07(2 \mathrm{H}, \mathrm{m})$ \\
\hline 21 & $1.44(2 \mathrm{H}, \mathrm{m})$ & $\begin{array}{l}1.54(1 \mathrm{H}, \mathrm{m}) \\
1.41(1 \mathrm{H}, \mathrm{m})\end{array}$ & $1.44(2 \mathrm{H}, \mathrm{m})$ & $1.36(2 \mathrm{H}, \mathrm{m})$ & $1.45(2 \mathrm{H}, \mathrm{m})$ \\
\hline 22 & $1.52(2 \mathrm{H}, \mathrm{m})$ & $\begin{array}{l}1.56(1 \mathrm{H}, \mathrm{m}) \\
1.42(1 \mathrm{H}, \mathrm{m})\end{array}$ & $1.61(2 \mathrm{H}, \mathrm{m})$ & $1.53(2 \mathrm{H}, \mathrm{m})$ & $1.54(2 \mathrm{H}, \mathrm{m})$ \\
\hline 23 & $4.9(1 \mathrm{H}, \mathrm{m})$ & $4.93(1 \mathrm{H}, \mathrm{m})$ & $4.95(1 \mathrm{H}, \mathrm{m})$ & $4.92(1 \mathrm{H}, \mathrm{m})$ & $4.94(1 \mathrm{H}, \mathrm{m})$ \\
\hline 24 & $1.2(3 \mathrm{H}, \mathrm{d}, 6.27)$ & $1.2(3 \mathrm{H}, \mathrm{d}, 6.27)$ & $1.22(3 \mathrm{H}, \mathrm{d}, 6.25)$ & $1.19(3 \mathrm{H}, \mathrm{d}, 6.27)$ & $1.2(3 \mathrm{H}, \mathrm{d}, 6.27)$ \\
\hline $1^{\prime}$ & & & & & \\
\hline $2^{\prime}$ & & $3.39(2 \mathrm{H}, \mathrm{s})$ & & & $2.47(2 \mathrm{H},-)$ \\
\hline $3^{\prime}$ & & & & & $2.50(2 \mathrm{H},-)$ \\
\hline $4^{\prime}$ & & & & & \\
\hline
\end{tabular}

The assignments were aided by $1 \mathrm{H}-1 \mathrm{H}$ COZY, DEPT, HMQC, HMBC, and selective homonuclear decoupled spectra.

technique, which is a very effective method of determining the coupling constants more accurately, was utilized for analysis of the ${ }^{1} \mathrm{H}$ NMR spectrum, thereby determining the geometric configurations (data not shown). Furthermore, the ${ }^{13} \mathrm{C}$ NMR spectrum (Table 3) evidenced an ester carbonyl resonance at $165.89 \mathrm{ppm}$ and 12 methine carbons between 67.14 and $143.82 \mathrm{ppm}$ assigned to six double bonds (Table $3)$. As a result, compound I was identified as a macrolactin compound. The specific rotation was shown to be $-10(C=4.0$ in $\mathrm{MeOH}$ ) at $17^{\circ} \mathrm{C}$ this is similar to the reported rotation of MA $[8,11,21]$. Based on these data, compound I was identified as MA (Fig. 1).

The production yield of compound II was $16 \mathrm{mg}$ per liter of fermentation broth. The purity was $84.88 \%$ on the HPLC chromatogram observed at a UV wavelength of $262 \mathrm{~nm}$. Compound II displayed not only mass-to-charge ratios of $511.7[\mathrm{M}+\mathrm{Na}]^{+}$and $487.7[\mathrm{M}-\mathrm{H}]^{-}$in the ESI-mass spectra, but also maximal absorptions of 230 and $258 \mathrm{~nm}$ in the UV spectrum. The NMR spectra of compound II were nearly identical to those described by Romero-Tabarez et al., in that the 7-H signal was shifted approximately $1.2 \mathrm{ppm}$ downfield [21]. The ${ }^{13} \mathrm{C}$ signals equivalent to the malonyl residue were identified at 166.47 and 168.27 ppm, and the direction of specific rotation was identified as levorotatory (-). These data, together with the ${ }^{1} \mathrm{H}-{ }^{1} \mathrm{H}$ COZY, HMQC and HMBC NMR spectra, helped to define the structure of compound II as MMA (Fig. 1, Table 2-3).

Compounds III and IV evidenced peaks at $424.0[\mathrm{M}+\mathrm{Na}]^{+}$ 
Table 3. ${ }^{13 \mathrm{C}} \mathrm{NMR}$ data $(125 \mathrm{MHz})$ of compounds $1-5$ in DMSO- $d b^{a}$

\begin{tabular}{|c|c|c|c|c|c|}
\hline Carbon No. & 1 & 2 & 3 & 4 & 5 \\
\hline 1 & $165.89 \mathrm{C}$ & $165.75 \mathrm{C}$ & $165.61 \mathrm{C}$ & $165.84 \mathrm{C}$ & $165.28 \mathrm{C}$ \\
\hline 2 & $117.04 \mathrm{CH}$ & $117.88 \mathrm{CH}$ & $116.61 \mathrm{CH}$ & $117.05 \mathrm{CH}$ & $117.35 \mathrm{CH}$ \\
\hline 3 & $143.82 \mathrm{CH}$ & $143.3 \mathrm{CH}$ & $143.38 \mathrm{CH}$ & $143.86 \mathrm{CH}$ & $142.82 \mathrm{CH}$ \\
\hline 4 & $128.49 \mathrm{CH}$ & $129.35 \mathrm{CH}$ & $128.0 \mathrm{CH}$ & $128.63 \mathrm{CH}$ & $128.88 \mathrm{CH}$ \\
\hline 5 & $142.73 \mathrm{CH}$ & $139.72 \mathrm{CH}$ & $142.01 \mathrm{CH}$ & $141.88 \mathrm{CH}$ & $139.50 \mathrm{CH}$ \\
\hline 6 & $42.23 \mathrm{CH} 2$ & $38.74 \mathrm{CH} 2$ & $41.29 \mathrm{CH} 2$ & $41.68 \mathrm{CH} 2$ & $38.37 \mathrm{CH} 2$ \\
\hline 7 & $70.02 \mathrm{CH}$ & $73.64 \mathrm{CH}$ & $70.24 \mathrm{CH}$ & $70.55 \mathrm{CH}$ & $72.23 \mathrm{CH}$ \\
\hline 8 & $137.86 \mathrm{CH}$ & $131.03 \mathrm{CH}$ & 137. $56 \mathrm{CH}$ & $137.91 \mathrm{CH}$ & $130.96 \mathrm{CH}$ \\
\hline 9 & $124.01 \mathrm{CH}$ & $126.93 \mathrm{CH}$ & $124.03 \mathrm{CH}$ & $124.48 \mathrm{CH}$ & $126.09 \mathrm{CH}$ \\
\hline 10 & $129.91 \mathrm{CH}$ & $129.26 \mathrm{CH}$ & $130.07 \mathrm{CH}$ & $130.32 \mathrm{CH}$ & $128.78 \mathrm{CH}$ \\
\hline 11 & $128.16 \mathrm{CH}$ & $130.26 \mathrm{CH}$ & $127.22 \mathrm{CH}$ & $127.65 \mathrm{CH}$ & $129.63 \mathrm{CH}$ \\
\hline 12 & $35.86 \mathrm{CH} 2$ & $35.8 \mathrm{CH} 2$ & $34.75 \mathrm{CH} 2$ & $35.28 \mathrm{CH} 2$ & $35.27 \mathrm{CH} 2$ \\
\hline 13 & $67.14 \mathrm{CH}$ & $67.07 \mathrm{CH}$ & $67.0 \mathrm{CH}$ & $67.0 \mathrm{CH}$ & $66.67 \mathrm{CH}$ \\
\hline 14 & $43.82 \mathrm{CH} 2$ & $43.81 \mathrm{CH} 2$ & $45.83 \mathrm{CH} 2$ & $49.32 \mathrm{CH} 2$ & $43.54 \mathrm{CH} 2$ \\
\hline 15 & $67.59 \mathrm{CH}$ & $67.53 \mathrm{CH}$ & $198.94 \mathrm{C}$ & 209.17 C & $67.13 \mathrm{CH}$ \\
\hline 16 & $136.41 \mathrm{CH}$ & $136.48 \mathrm{CH}$ & $128.80 \mathrm{CH}$ & $43.06 \mathrm{CH} 2$ & $135.98 \mathrm{CH}$ \\
\hline 17 & $128.63 \mathrm{CH}$ & $128.62 \mathrm{CH}$ & $143.28 \mathrm{CH}$ & $26.69 \mathrm{CH} 2$ & $128.19 \mathrm{CH}$ \\
\hline 18 & $130.68 \mathrm{CH}$ & $130.67 \mathrm{CH}$ & $129.08 \mathrm{CH}$ & $129.42 \mathrm{CH}$ & $130.19 \mathrm{CH}$ \\
\hline 19 & $133.46 \mathrm{CH}$ & $133.31 \mathrm{CH}$ & $144.85 \mathrm{CH}$ & $130.52 \mathrm{CH}$ & $132.88 \mathrm{CH}$ \\
\hline 20 & $31.82 \mathrm{CH} 2$ & $31.74 \mathrm{CH} 2$ & $31.82 \mathrm{CH} 2$ & $31.84 \mathrm{CH} 2$ & $31.33 \mathrm{CH} 2$ \\
\hline 21 & $24.49 \mathrm{CH} 2$ & $24.49 \mathrm{CH} 2$ & $23.82 \mathrm{CH} 2$ & $24.92 \mathrm{CH} 2$ & $24.08 \mathrm{CH} 2$ \\
\hline 22 & $34.74 \mathrm{CH} 2$ & $34.72 \mathrm{CH} 2$ & $34.50 \mathrm{CH} 2$ & $34.99 \mathrm{CH} 2$ & $34.29 \mathrm{CH} 2$ \\
\hline 23 & $70.57 \mathrm{CH}$ & $70.61 \mathrm{CH}$ & $69.96 \mathrm{CH}$ & $70.33 \mathrm{CH}$ & $70.17 \mathrm{CH}$ \\
\hline 24 & $19.97 \mathrm{CH} 3$ & $19.96 \mathrm{CH} 3$ & $19.55 \mathrm{CH} 3$ & $20.14 \mathrm{CH} 3$ & $19.50 \mathrm{CH} 3$ \\
\hline $1^{\prime}$ & & $166.47 \mathrm{C}$ & & & $171.30 \mathrm{C}$ \\
\hline $2^{\prime}$ & & $42.02 \mathrm{CH} 2$ & & & $28.61 \mathrm{CH} 2$ \\
\hline $3^{\prime}$ & & $168.27 \mathrm{C}$ & & & $28.78 \mathrm{CH} 2$ \\
\hline $4^{\prime}$ & & & & & $173.18 \mathrm{C}$ \\
\hline
\end{tabular}

The assignments were aided by $1 \mathrm{H}-1 \mathrm{H}$ COZY, DEPT, HMQC, and HMBC spectra.

and $426.0[\mathrm{M}+\mathrm{Na}]^{+} \mathrm{m} / \mathrm{z}$, respectively, in the $(+)$ ESI spectrum. Additionally, compound III evidenced maximum absorbance at $264 \mathrm{~nm}$, whereas compound IV evidenced maximum resonance at $262 \mathrm{~nm}$. The purities of III and IV were $98.9 \%$ and $90.8 \%$, respectively, on the HPLC chromatogram observed at a UV wavelength of $262 \mathrm{~nm}$. The production yields of compounds III and IV were 3 and $5 \mathrm{mg}$ per liter of fermentation broth, respectively. The NMR data of compound III was nearly identical to that of MA, except for the absence of a $15-\mathrm{H}$ resonance, the appearance of $16-\mathrm{H}$ as a doublet at $5.99 \mathrm{ppm}(\mathrm{d}, \mathrm{J}=15.56 \mathrm{~Hz})$ and a downfield shift of the protons $(16-\mathrm{H}, 17-\mathrm{H}, 18-\mathrm{H}$ and $19-\mathrm{H})$ in the ${ }^{1} \mathrm{H}-$ NMR spectrum (Table 2). Our comparison of the ${ }^{13} \mathrm{C}$ NMR spectra of compound III and MA suggested that they differed only in terms of the presence of ketone in compound III (Table 3). The structure of compound III was identical to that of ME, based on the totality of the data [8]. The NMR data of compound IV were nearly identical to those of ME, except for the appearance of $14-\mathrm{H}$ as a doublet at $2.44 \mathrm{ppm}$ (d, $\mathrm{J}=6.51 \mathrm{~Hz}$ ), the existence of $16-\mathrm{H}$ as a triplet at $2.38 \mathrm{ppm}$ $\left(\mathrm{t}, \mathrm{J}=7.745 \mathrm{~Hz}\right.$ ) in the ${ }^{1} \mathrm{H}$ NMR spectrum, a downfield shift of the 15-C (209.17 ppm) and the appearance of two additional aliphatic methylenes in the ${ }^{13} \mathrm{C}$ NMR spectrum. The NMR spectra of compound IV together with the LC/Mass data helped to define the structure of compound IV as MF (Fig. 1) [8].

The production yield of compound V was $138 \mathrm{mg}$ per liter of fermentation broth. Compound $\mathrm{V}$ evidenced a purity of $97.02 \%$ on the HPLC chromatogram, $525.6 \mathrm{~m} / \mathrm{z}$ of $[\mathrm{M}+\mathrm{Na}]+$ in the $(+)$ ESI spectrum, $501.6 \mathrm{~m} / \mathrm{z}$ of $[\mathrm{M}-\mathrm{H}]-$ in the (-) ESI spectrum, and maximum absorbance at a UV wavelength of $258 \mathrm{~nm}$. The specific rotation was -15 (C=4.0 in $\mathrm{MeOH}$ ) at $17^{\circ} \mathrm{C}$. The NMR data of compound $\mathrm{V}$ were nearly identical to those of MMA except for the appearance of 2'-H (2.47 ppm), 3'-H (2.5 ppm), 1'-C (C, 171.3042), 2'-C $(\mathrm{CH} 2,28.6109), 3^{\prime}-\mathrm{C}(\mathrm{CH} 2,28.7757)$ and $4^{\prime}-\mathrm{C}(\mathrm{C}, 173.1817)$ signals, which reflected the existence of succinyl residues. The NMR spectra and the specific rotation value of com- 

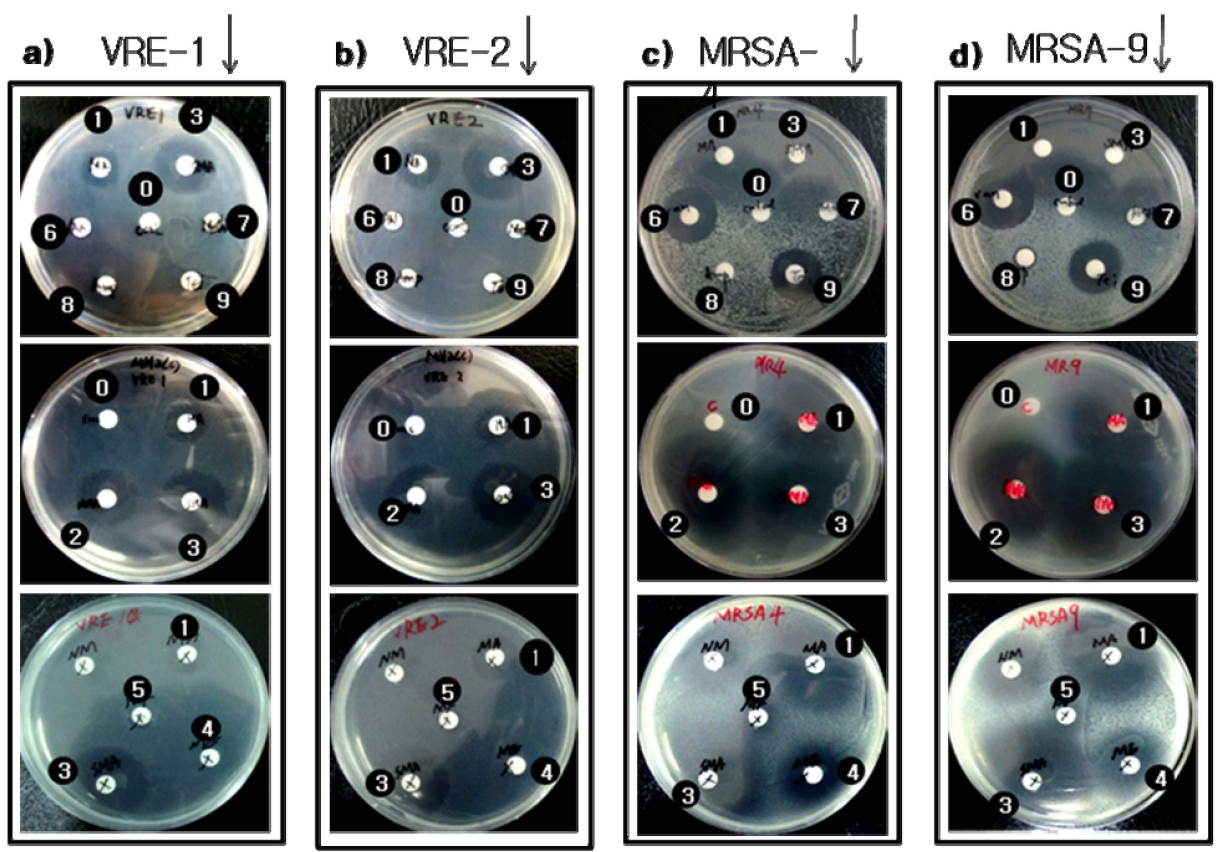

Fig. 3. The growth inhibition zones of five macrolactins and reference compounds against VREs and MRSAs. a) and b) indicates the growth inhibition of VRE-1 and VRE-2 $\left(5 \times 10^{5} \mathrm{cfu} /\right.$ plate $)$ treated with the test compounds, respectively. Each of c) and d) indicates the growth inhibition of MRSA- 4 and MRSA-9 $\left(0.5 \sim 5 \times 10^{5} \mathrm{cfu} / \mathrm{plate}\right)$ with them. $0, \mathrm{MeOH}$ as a control; 1 , macrolactin A; 2, 7-O-malonyl macrolactin A; 3, 7-O-succinyl macrolactin A; 4, macrolactin E; 5, macrolactin F; 6, vancomycin; 7, methicillin; 8, ampicillin; 9, teicoplanin. Each disc is compromising $50 \mu \mathrm{g}$ of the test compounds. VRE1/2, vancomycin-resistant Enterococcus faecium-1/2. MRSA-4/9, methicillin-resistant Staphylococcus aureus4/9.

pound $\mathrm{V}$ were almost identical to those of SMA [10]. The LC/Mass data and the NMR data showed that compound $\mathrm{V}$ was an SMA [10]

Antibacterial activities of the five macrolactin compounds

The antibacterial activities of the purified macolactin compounds against reference strains and clinical isolates were evaluated using a paper disc agar diffusion bioassay (Table 4) and representative results are shown in Fig. 3. All five of the macrolactin compounds inhibited the growth of S. aureus, MRSA-4 and MRSA-9 and three of them (MA, MMA, and SMA) inhibited the growth of E. faecalis, VRE-1, and VRE-2. Furthermore, the antibacterialactivities of MA, MMA,and SMA against both VRE and MRSA were superior to those of vancomycin and teicoplanin.

\section{Discussion}

We purified five macrolactin compounds from a fermentation broth of BP2 [12] and elucidated their structures. The macrolactin compounds were MA, MMA, SMA, ME and MF.
The antibacterial activities of the macrolactin compounds against reference strains and clinical isolates were evaluated via a paper disc agar diffusion bioassay. Three macrolactin compounds, MA, MMA,and SMA (but not ME and MF) inhibited the growth of both MRSA and VRE. ME and MF proved active against MRSA, but were not active against VRE. The principal structural difference between MA/MMA /SMA and ME/MF was the presence of the C-15 hydroxyl group. Nagao et al. reported that the hydroxyl group at C-15 might perform an important function in the antibacterial activity of macrolactin compounds [16]. Our results also suggest that the C-15 hydroxyl group of macrolactins could exert an effect on the antibacterial activity. We attempted to determine the MIC value for the macrolactins, but they did not completely inhibit the growth of the strains via the agar diffusion method. The same results were reported by Romero-Tabarez et al. [21]

The production levels of MA, MMA, SMA, ME, and MF were $58 \mathrm{mg}, 16 \mathrm{mg}, 138 \mathrm{mg}, 3 \mathrm{mg}$ and $5 \mathrm{mg}$ per L of fermentation broth, respectively. The production yield of macrolactins has generally been approximately $3 \mathrm{mg} / \mathrm{l}$, according to the reports published thus far $[8,10,11,14,16,21,27]$. Based 
on these results, B. polyfermenticus KJS-2 is apparently a potentially valuable and effective strain for the production of macrolactin compounds.

The three macrolactin compounds--MA, MMA, and SMA--evidenced profound antibacterial activity against the clinical isolates of MRSA and VRE, and their levels of activity were superior to those of vancomycin and teicoplanin. The potential activity of macrolactins should be evaluated by in vivo experiments in the future, owing to the somewhat ambiguous MIC data this will be our next topic of inquiry.

\section{Acknowledgement}

This research was supported by a Kyungsung University Research Grant in 2010.

\section{References}

1. Arthur, M. and R. Quintiliani. 2001. Regulation of VanA and VanB type glycopeptide resistance in enterococci. Antimicrob. Agents Chemother. 45, 375-381.

2. Auckland, C., L. Teare, F. Cooke, M. E. Kaufmann, M. Warner, G. Jones, K. Bamford, H. Ayles, and A. P. Johnson. 2002. Linezolid-resistant enterococci: report of the first isolates in the United Kingdom. J. Antimicrob. Chemother. 50, 743-746.

3. Bagga, B. and J. L. Shenep. 2010. Management of infections caused by vancomycin-resistant Gram-positive bacteria. Pediatr. Infect. Dis. J. 29, 662-664.

4. Choi, S. W., D. H. Bai, J. H. Yu, and C. S. Shin. 2003. Characteristics of the squalene synthase inhibitors produced by a Streptomyces species isolated from soils. Can. J. Microbiol. 49, 663-668.

5. Cosgrove, S. E., G. Sakoulas, E. N. Perencevich, M. J. Schwaber, A. W. Karchmer, and Y. Carmeli. 2003. Comparison of mortality associated with methicillin-resistant and methicillin-susceptible Staphylococcus aureus bacteremia: A meta-analysis. Clin. Infect. Dis. 36, 53-59.

6. Fraser, T. G., C. Hansen, and J. K. Long. 2006. Newer antibiotics for serious gram-positive infections. Cle. Clin. J. Med 73, 847-853

7. Goll, C., P. Balmer, F. Schwab, H. Rüden, and T. Eckmanns. 2007. Different trends of MRSA and VRE in a German Hospital, 1999-2005. Infection 35, 245-249.

8. Gustafson, K., M. Roman, and W. Fenical. 1989. The macrolactins, a novel class of antiviral and cytotoxic macrolides from a deep-sea marine bacterium. J. Am Chem Soc. 111, 7519-7524.

9. Han, J. S., J. H. Cheng, T. M. Yoon, J. Song, A. Rajkarnikar, W. G. Kim, I. D. Yoo, and Y. Y. Yang. 2005. Biological control agent of common scab disease by antagonistic strain Bacillus sp. sunhua. J. Appl. Microbiol. 99, 213-221.
10. Jaruchoktaweechai, C., K. Suwanborirux, S. Tanasupawatt, P. Kittakoop, and P. Menasveta. 2000. New macrolactins from a marine Bacillus sp. Sc026. J. Nat. Prod 63, 984-986.

11. Kim, H. H., W. G. Kim, I. J. Ryoo, C. J. Kim, J. E. Suk, K. H. Han, S. Y. Hwang, and I. D. Yoo. 1997. Neuronal cell protection activity of macrolactin A produced by Actinomadura sp. J. Microbiol. Biotechnol. 7, 429-434.

12. Kim, K. M., M. J. Kim, D. H. Kim, Y. S. Park, and J. S. Kang. 2009. Characterization of Bacillus polyfermenticus KJS-2 as a Probiotic. J. Microbiol. Biotechnol. 19, 1013-1018.

13. Lee, K. H., K. D. Jun, W. S. Kim, and H. D. Paik. 2001. Partial characterization of polyfermenticin SCD, a newly identified bacteriocin of Bacillus polyfermenticus. Lett. Appl. Microbiol. 32, 146-151.

14. Lee, S. J., J. Y. Cho, J. H. Moon, K. D. Park, Y. J. Lee, and K. H. Park. 2004. Isolation and characterization of antimicrobial substance macrolactin A produced from Bacillus amyloliquefaciens $\mathrm{CHO} 104$ isolated from soil. J. Microbiol. Biotechnol. 14, 525-531.

15. Lentino, J. R., M. Narita, and V. L. Yu. 2008. New antimicrobial agents as therapy for resistant gram-positive cocci. Eur. J. Clin. Microbiol. Infect. Dis. 27, 3-15.

16. Nagao, T., M. Adachi, M. Sakai, M. Nishijima, and H. Sano. 2001. Novel macrolactins as antibiotic lactones from a marine bacterium. J. Antibiot. 54, 333-339.

17. Neu, H. C. 1992. The crisis in antibiotic resistance. Science 254, 1064-1073.

18. Norrby, S. R. 1995. Emerging antibiotic resistance in Gram positive bacteria: return to the pre-antibiotic era? HKMJ. 1, 129-135.

19. Presterl, E., W. Graninger, and A. Georgopoulos. 1993. The efficacy of teicoplanin in the treatment of endocarditis caused by Gram-positive bacteria. J. Antimicrob. Chemother. 31, 755-766.

20. Rice, L. B. 2006. Antimicrobial resistance in gram-positive bacteria. Am J. Infect. Control. 34, S11-S19.

21. Romero-Tabarez, M., R. Jansen, M. Sylla, H. Lunsdorf, S. Haubler, D. A. Santosa, K. N. Timmis, and G. Molinari. 2006. 7-O-malonyl macrolactin $\mathrm{A}$, a new macrolactin antibiotic from Bacillus subtilis active against methicillin-resistant Staphylococcus aureus, vancomycin-resistant Enterococci, and a small-colony variant of Burkholderia cepacia. Antimicrob. Agents Chemother. 50, 1701-1709.

22. Sohn, M. J., C. J. Zheng, and W. G. Kim. 2008. Macrolactin $\mathrm{S}$, a new antibacterial agent with Fab G-inhibitory activity from Bacillus sp. AT28. J. Antibiot. 61, 687-691.

23. Tsiodras, S., H. S. Gold, G. Sakoulas, G. M. Eliopoulos, C. Wennersten, L. Venkataraman, and R. C. Moellering. 2001. Linezolid resistance in a clinical isolate of Staphylococcus aureus. Lancet 358, 207-208.

24. Van der Auwera, P., M. Aoun, and F. Meunier. 1991. Randomized study of vancomycin versus teicoplanin for the treatment of gram-positive bacterial infections in immunocompromised hosts. Antimicrob. Agents Chemother. 35, 451-457.

25. Von Baum, H., J. F. Ober, C. Wendt, R. P. Wenzel, and M. 
B. Edmond. 2005. Antibiotic-resistant bloodstream infections in hospitalized patients: specific risk factors in a high-risk population? Infection. 33, 320-326.

26. Xue, C., L. Tian, M. Xu, Z. Deng, and W. Lin. 2008. A new 24-membered lactone and a new polyene $\delta$-lactone from the marine bacterium Bacillus Marinus. J. Antibiot. 61, 668-674.

27. Yoo, J. S., C. J. Zheng, S. K. Lee, J. H. Kwak, and W. G. Kim. 2006. Macrolactin N, a new peptide deformylase inhibitor produced by Bacillus subtilis. Bioarg. Med Chem Lett.
16, 4889-4892.

28. Zheng, C. J., S. K. Lee, C. H. Lee, and W. G. Kim. 2007. Macrolactins O-R, glycosylated 24-membered lactones from Bacillus sp. AH159-1. J. Nat. Prod 70, 1632-1635.

29. Zurenko, G. E., B. H. Yagi, R. D. Schaadt, J. W. Allison, J. O. Kilburn, S. E. Glickman, D. K. Hutchinson, M. R. Barbachyn, and S. J. Brickner. 1996. In vitro activities of U-100592 and U-100766, novel oxazolidinone antibacterial agents. Antimicrob. Agents Chemother. 40, 839-845.

\section{초록 : Bacillus polyfermenticus KJS-2에서 분리된 항생물질 마크로락틴류의 구조결정}

김동희 ${ }^{1} \cdot$ 강경란 $^{1} \cdot$ 김현우 ${ }^{2} \cdot$ 윤시열 $^{3} \cdot$ 김천규 $^{3} \cdot$ 토쿠타로 야마구치 $\left.\right|^{4} \cdot$ 송재경 ${ }^{4} \cdot$ 강재선 $^{5} \star$

( ${ }^{1}$ 대우제약 연구소, ${ }^{2}$ 대선주조 연구소, ${ }^{3}$ 인제대학교 제약공학과, ${ }^{4}$ 선문대학교 제약공학과, ${ }^{5}$ 경성대학교 약학대학)

바실러스 폴리퍼멘티쿠스 케이제이에스-2의 발효액에서 5 종류의 마크로락틴을 분리하였다. 각각의 구조를 분 석한 결과로 마크로락틴 에이, 말로닐 마크로락틴 에이, 숙시닐 마크로락틴 에이, 마크로락틴 이, 마크로락틴 에 프 등으로 규명되었다. 특히 3종의 항생제인 마크로락틴 에이, 말로닐 마크로락틴 에이, 숙시닐 마크로락틴 에이 는 반코마이신 내성 장구균과 메치실린 내성 황생포도상구균에 효과적으로 성장억제를 나타내었다. 이것은 반코 마이신이나 테이코플라닌보다 우수한 항생효과를 보였다. 